\title{
Bir Nöromüsküler Hastalıklar Merkezinden Herediter Polinöropati Hastalarının Klinik, Elektrofizyolojik ve Genetik Profili
}

\section{Clinical, Electrophysiological and Genetic Profile of Hereditary Polyneuropathy Patients From a Single Center of Neuromuscular Diseases}

\author{
Onur AKAN, Tuğçe AKSU UZUNHAN $\stackrel{2}{2}$ Biray ERTÜRK $\stackrel{3}{\text {, Leyla BAYSAL KIRAÇ }}$ \\ 1 Sağlık Bilimleri Üniversitesi, Prof. Dr. Cemil Taşcıoğlu Şehir Hastanesi, Nöroloji Anabilim Dalı, İstanbul, Türkiye \\ 2 Sağlık Bilimleri Üniversitesi, Prof. Dr. Cemil Tașcıoğlu Șehir Hastanesi, Cocuk Nöroloji Anabilim Dalı, İstanbul, Türkiye \\ 3 Sağılk Bilimleri Üniversitesi, Prof. Dr. Cemil Taşcıŏlu Şehir Hastanesi, Tıbbi Genetik Anabilim Dalı, İstanbul, Türkiye \\ 4 Trakya Üniversitesi Hastanesi, Nöroloji Anabilim Dalı, Edirne, Türkiye
}

Yazışma Adresi

Correspondence Address

\section{Onur AKAN}

Sağlık Bilimleri Üniversitesi,

Prof. Dr. Cemil Taşcıoğlu Şehir

Hastanesi, Nöroloji Anabilim Dalı,

İstanbul, Türkiye

dronurakan@hotmail.com

Geliș tarihi / Received : Kasım 13, 2020 Kabul tarihi / Accepted : Mart 12, 2021 Elektronik yayın tarihi : Ocak 01, 2022 Online published

Bu makalede yapılacak atıf: Cite this article as:

Akan O, Aksu Uzunhan T,

Ertürk B, Baysal Kıraç L.

Bir Nöromüsküler Hastalıklar

Merkezinden Herediter

Polinöropati Hastalarının Klinik,

Elektrofizyolojik ve Genetik Profili.

Akd Tıp D 2022; 8(1):68-74.

\section{Onur Akan}

ORCID 0000-0001-8520-670X

Tuğçe Aksu Uzunhan

ORCID 0000-0003-0596-2690

Biray Ertürk

ORCID 0000-0002-0348-6267

Leyla Baysal Kıraç

ORCID 0000-0001-6647-4485

\section{öz}

\section{Giriş/Amaç:}

Herediter polinöropati ön tanılı olguların klinik ve elektrofizyolojik özelliklerinin gözden geçirilmesi.

\section{Gereç ve Yöntemler:}

Erişkin ve çocuk nöroloji kliniklerinde takip edilen ve tıbbi genetik laboratuvarına rutin tanı testi amacıyla yönlendirilen herediter polinöropati ön tanılı 75 hastanın dosyaları retrospektif olarak incelendi. Olgular, genetik test sonuçlarına göre Charcot Marie Tooth (CMT) 1A, herediter basınca duyarlı polinöropati (HNPP) ve mutasyon saptanmayanlar şeklinde üç gruba ayrılarak klinik özellikleri ve elektrofizyolojik bulgularına göre değerlendirildi.

\section{Bulgular:}

Çalışmaya alınan $45(\% 60)$ erkek, $30(\% 40)$ kadın toplam 75 olgunun yaş ortalaması

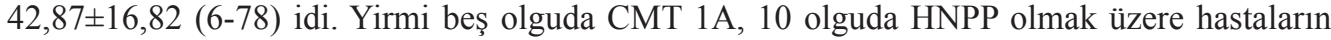
$\% 46$ 'sında genetik inceleme ile tanıya ulaşıldı. CMT 1A hastalarında en sık saptanan nörolojik muayene bulgusu distal kas atrofisi ve arefleksi/hiporefleksi olup bunların 21'inde ayak deformitesi mevcuttu. Diğer taraftan HNPP tanısı alan hastalarda en sık nörolojik muayene bulgusu birden fazla periferik sinirde duyu kaybı ile birlikte asimetrik distal kuvvetsizlik olup bu olguların ikisinde ayak deformitesi tespit edildi. Mutasyon saptanmayan 40 olgunun nörolojik muayenelerinde ise yine en sık bulgu distal kas atrofisi ve arefleksi/hiporefleksi idi. Aile öyküsü alınmayan 4 olguda CMT 1A, 3 olguda ise HNPP saptandi.

\section{Sonuç:}

Aile öyküsü negatif olsa da spesifik klinik ve elektrofizyolojik ipuçları varlı̆̆ında hastaların uygun genetik testlere yönlendirilmesi önemlidir.

Anahtar Sözcükler: Herediter polinöropati, Charcot-Marie-Tooth (CMT) hastalı̆̆ı, PMP 22 gen mutasyonu, Elektromiyografi

\section{ABSTRACT}

Objective:

To assess the clinical and electrophysiological features of patients with a pre-diagnosis of hereditary polyneuropathy. 


\section{Methods:}

The files of 75 patients with a pre-diagnosis of hereditary polyneuropathy who were followed up in adult and pediatric neurology clinics and referred to the medical genetics laboratory for routine diagnostic testing were retrospectively reviewed. According to the genetic results, the cases were divided into three groups as Charcot Marie Tooth (CMT 1A), hereditary neuropathy with liability to pressure palsies (HNPP), and those without the mutation. The clinical features and electrophysiological findings of the patients were evaluated.

\section{Results:}

A total of 75 cases, $45(60 \%)$ male and $30(40 \%)$ female, were included in the study. The mean age of the patients was 42.87 \pm 16.82 (6-78). The diagnosis was achieved by genetic examination in $46 \%$ of the patients, including CMT $1 \mathrm{~A}$ in 25 cases and HNPP in 10 cases. The most common neurological examination findings in CMT 1A patients were distal muscle atrophy and areflexia/ hyporeflexia, and 21 of these CMT 1A patients had foot deformity. The most common neurological examination finding in patients diagnosed with HNPP was asymmetric distal weakness with loss of sensation in more than one peripheral nerve and foot deformity was detected in two of these cases. CMT 1A was detected in 4 cases and HNPP was detected in 3 cases without a family history.

\section{Conclusion:}

Although the family history is negative, it is important to refer patients to appropriate genetic tests in the presence of specific clinical and electrophysiological clues.

Key Words: Hereditary polyneuropathy, Charcot-Marie-Tooth (CMT) disease, PMP 22 gene mutation, Electromyography

\section{GIRIŞ}

Kalıtsal periferik nöropatiler, 2500 kişide bir prevelans ile en yaygın kalıtsal nörolojik hastalıklar arasında olup hafif semptomatik formlardan ağır formlara kadar geniş bir yelpazeyi kapsayan, klinik olarak heterojen bir grup hastalıktan oluşur $(1,2)$. Bunlar arasında en sik görüleni Charcot-Marie-Tooth (CMT) hastalı̆̆ 1 , diğer adiyla herediter motor ve duysal nöropatidir. Klasik CMT hastalığı, distal duyu kaybı ve kas zayıflığı, derin tendon refleks anormallikleri ve iskelet deformiteleri ile karakterize edilen uzunluğa bağlı aksonal dejenerasyonu yansıtır. Bugüne kadar CMT hastalığı ile ilişkili 80 'den fazla nedensel geni tanımlanmakla birlikte daha pek çok gen de bilinmemektedir. Dört demiyelinizan alt tip (CMT1A, CMT1X, herediter basinca duyarlı nöropati ve CMT1B) genetik olarak tanımlanabilen kalıtsal nöropatilerin \%88'ini temsil eder (3). CMT hastaların yaklaş1k \%55'inde görülen ve en yaygın tanımlanabilir alt formu olan CMT1A, PMP22 geninin kromozom 17 üzerinde yer alan k1sa bir parçanın duplikasyonundan kaynaklanır. Herediter basınca duyarlı nöropati (HNPP) alt tipi ise yine ayn1 PMP22 genindeki delesyonlar nedeniyle otozomal dominant kalıtım- la geçen ve kalıtsal nöropati hastalarının \%9'unda görülen bir hastalıktır. CMT 2 aksonal transport, membran trafiği gibi intraselüler süreçleri etkileyen genleri ilgilendiren, otozomal dominant kalıtım özellikleri sergileyen daha nadir görülen formdur (4,5). CMT hastalığı için mevcut genetik test algoritmaları, klinik değerlendirme, ayrıntılı aile öyküsü ve kapsamlı nörofizyolojik verilere dayanmaktadır (6). Herediter polinöropati hastalarında belirli klinik ve elektromiyografi (EMG) bulguları varlığında genetik test istenmesi önemlidir. $\mathrm{Bu}$ retrospektif çalışmada, CMT 1A hedefli gen paneli çalışılan herediter polinöropati ön tanılı olguların klinik ve elektrofizyolojik özelliklerinin gözden geçirilmesi amaçlandi.

\section{GEREÇ ve YÖNTEM}

Çalışmada, 2016-2020 yılları arasında SBÜ Prof. Dr. Cemil Taşcıŏglu Şehir Hastanesi nöroloji kliniği nöromüsküler hastalıklar ve çocuk nöroloji polikliniğinden takip edilen, edinsel nöropatinin diğer yaygın nedenleri dışlanmış, yavaş ilerleyen kronik nöropatili 75 hastanın tıbbi dosyaları retrospektif olarak incelendi. Hastaların yaşı, yakınması, aile öyküsü, nörolojik muayene bulguları, laboratuvar ve elektrofizyolojik bulguları ile genetik test sonuçları kaydedildi. Şikayetleri akut ya da subakut olarak başlayan olgular ile polinöropati etyolojisi araştırılırken başka bir etyolojik neden saptanmış olgular (inflamatuvar, diyabetik, metabolik, toksik ve paraneoplastik nedenlere bağlı olgular) çalışmaya dahil edilmedi. Klinik verileri yetersiz olan 7 olgu çalışma dışı bırakıldı. Aile öyküsü gözetilmeksizin klinik öyküsü ve elektrofizyolojik bulguları CMT hastalığı ile uyumlu olan hastalar çalışmaya dahil edildi. Ayırıcı tanı yapılırken herediter nöropati şüphesiyle genetik inceleme yapılan olgular da çalışmaya dahil edildi. Olguların demografik verileri, aile öyküsü, nörolojik muayene bulguları ve EMG sonuçları hasta dosyalarından kaydedildi.

\section{Klinik Bilgiler:}

Hastaların yaş, cinsiyet, fenotipik ve klinik bulguları, ailede benzer hastalık öyküsü ve kalıtım paterni varlığı kaydedildi. Sensorimotor polinöropati, uzunluğa bağlı duyu kaybı, güçsüzlük ve atrofinin yanı sıra azalmış derin tendon reflekslerinin varlığına göre teşhis edildi. Ayrıca bir veya birden fazla periferik sinirde duyu kaybı ile asimetrik distal kuvvetsizlik not edildi.

\section{Sinir İletim Çalışmaları:}

Polinöropatiyi doğrulamak için sinir iletim çalışmaları kullanıldı. Elektrofizyoloji incelemesi için standart yöntemler kullanıldı. EMG yapılırken ekstremite sıcaklıkları gözetildi. Sinir iletim çalışmalarında motor distal latansların en az iki sinirde üst sınırın \%50'sinden uzun olması ya da motor sinir ileti hızlarının en az iki sinirde alt sınırın \%30'undan düşük olması (üst ekstremitelerde $38 \mathrm{~m} / \mathrm{sn}$ altında, alt ekstremitelerde $30 \mathrm{~m} / \mathrm{sn}$ altında iletim hızları) demiyelinizan polinöropati olarak kabul edildi (7). Sinir ileti çalışmalarında tuzak yerleri dişında temporal dispersiyon ve ileti bloğu varlığı değerlendirildi. Sinir iletim hızında belirgin yavaşla- 
ma olmaksizın duysal cevap amplitüdü ve motor cevap amplitüdünde düşme aksonal polinöropati olarak kabul edildi (8). Hastaların EMG sonuçları uniform sensorimotor demiyelinizan polinöropati, uniform olmayan sensorimotor demiyelinizan polinöropati, sensorimotor aksonal polinöropati şeklinde sinıflandırıldı. Ayrıca aksonal/demiyelinizan polinöropati ayrımı yapılamayan ağır aksonal etkilenim ile sensorimotor polinöropati zemininde birden fazla periferik sinirde tuzak nöropati not edildi. Bunların yanı sıra median ve ulnar sinir tuzak nöropati birlikteliği ile peroneal sinir tuzak nöropatisi not edildi.

Genetik inceleme için tüm hastalardan aynı laboratuvarda çalışılmak üzere 2 cc EDTA'lı periferik kan alınarak DNA izolasyonu yapıldı. Kromozom 17q üzerindeki PMP 22 genini kapsayan 1.5 Mb'llk bölgenin kopya sayısı internal kontrollerle karşılaştırmalı olarak Multiplex ligation-dependent probe amplification (MLPA) yöntemi ile analiz edildi. Genetik sonuçlara göre CMT 1 A, HNPP saptanan olgular ve mutasyon saptanmayan olgular olmak üzere 3 gruba ayrilarak incelendi. Genetik test sonuçlarına göre PMP22 geni ile ilişkili mutasyon saptanan ve mutasyon saptanmayan hastaların klinik ve elektrofizyolojik özellikleri karşılaştırıldı. Çalışmada elde edilen bulguların istatistiksel analizi için IBM SPSS Statistics versiyon 22.0 (IBM SPSS, Türkiye) programı kullanıld. Tanımlayıcı istatistiksel analizler yapıldı. Kategorik ölçümler sayı ve yüzde olarak, sayısal ölçümlerse ortalama ve standart sapma (gerekli yerlerde minimum-maksimum) olarak belirtildi. Kategorik ölçümlerin gruplar arası karşılaştırılması pearson ki-kare testi ile yapıldı. Tüm testler için $\mathrm{p}<0,05$ değeri istatistiksel olarak anlamlı kabul edildi.

Çalışma için Prof. Dr. Cemil Taşcıoğlu Şehir Hastanesi etik komitesi tarafından izin alındı (02.06.2020/151) ve çalışma 1964 Helsinki Bildirisi'nde belirtilen etik standartlara göre yapıldı. Çalışmamızda araştırma ve yayın etiğine uyuldu.

\section{BULGULAR}

Çalışmaya dahil edilen 45 (\%60) erkek, 30 (\%40) kadın toplam 75 olgunun yaş ortalaması $42,87 \pm 16,82$ (6-78) idi. Hastaların \%33,3'nde CMT 1A, \%13,3'nde HNPP tanıs1 doğrulanarak \%46'sında genetik tanıya ulaşıldı. Gruplar arasında yaş ve cinsiyet açısından istatistiksel olarak anlamlı farklılik saptanmadi.

CMT 1A tanılı 25 olgunun 13'ü erkek, 12'si kadın olup yaş ortalamas1 43,4 $\pm 16,41$ (17-78) idi. Hastaların hepsinde distal kas atrofisi, arefleksi/hiporefleksi saptanmış olup bunların 21 'inde ayak deformitesi (pes cavus ya da çekiç parmak) mevcuttu. Asemptomatik olan iki olgu, hasta aile bireylerinin klinik viziti sırasında değerlendirilmeye alındı ve bu hastalarda genetik inceleme sonucu mutasyon tespit edildi. Kronik inflamatuvar demiyelinizan polinöropati (KIDP) ön tanısıyla izlenen ve immünomodülatör tedavilere yanıt alınamayan bir olguda alternatif tanıdan şüphelenilme neticesinde PMP22 duplikasyonu saptand. CMT 1 A olgularının 21'inde (\%84) ailede benzer hastalık öyküsü ve otozomal dominant kalıtım paterni mevcuttu. Dört olguda (\%16) ailede benzer hastalık yoktu. Tüm CMT 1A olgularının EMG incelemesinde uniform sensorimotor demiyelinizan polinöropati saptandi.
Genetik olarak HNPP tanısı doğrulanan 8 erkek, 2 kadın toplam 10 olgunun yaş ortalaması $38,4 \pm 15,31$ (14-64) idi. $\mathrm{Bu}$ hastalarda en s1k görülen nörolojik muayene bulgusu (\%70) birden fazla periferik sinirde duyu kaybı ile birlikte asimetrik distal kuvvetsizlikti. İki olguda ayak deformitesi ile birlikte distal kas atrofisi ve arefleksi/hiporefleksi mevcuttu. EMG incelemesinde HNPP olgularının tamamında sensorimotor polinöropati zemininde birden fazla periferik sinirde tuzaklanma saptandı. Tuzaklanmanın en s1k ulnar ve peroneal sinirde olduğu dikkati çekti. Ailede benzer hastalık öyküsü 7 olguda (\%70) mevcut olup otozomal dominant kalıtım paterni saptandı. Üç olguda (\%30) ailede benzer hastalık öyküsü yoktu.

Genetik mutasyon saptanmayan diğer grupta ise 24'ü erkek, 16 's1 kadın toplam $40(\% 53,3)$ olgunun yaş ortalaması $43,7 \pm$ 15,46 (6-70) idi. Nörolojik muayenelerinde en s1k bulgu $(\% 67,5)$ distal kas atrofisi, arefleksi/hiporefleksi idi. Yedi olguda birden fazla periferik sinirde duyu kaybı ile birlikte asimetrik distal kuvvetsizlik, 1 olguda bir periferik sinir dağılımına uyan duysal ve motor bulgular, 5 olguda izole ayak deformitesi mevcuttu. EMG incelemesi 34 hastaya yapıldı. Aksonal /demiyelinizan polinöropati ayrımı yapılamayan ağır aksonal etkilenim (\%32,5) en sık görülen bulguydu. Median ve ulnar sinir tuzak nöropati birlikteliği 8 olguda, sensorimotor aksonal polinöropati 5 olguda, uniform olmayan sensorimotor demiyelinizan polinöropati 4 olguda, peroneal tuzak nöropati 3 olguda, uniform sensorimotor demiyelinizan polinöropati 1 olguda mevcuttu. Akut lenfoblastik lösemi (ALL) nedeniyle lösemi tedavisi gören, ağır aksonal etkilenimi olan ve hızlı klinik progresyon gelişen bir olguda ayırıcı tanıya yönelik herediter polinöropati tanısı araştırılmıştı. KIDP ön tanısıyla izlenirken tedaviye yanıtsızlık durumu nedeniyle beş olgudan genetik inceleme istenmişti. Bu olgulardan birinin ileri incelemesinde önemi belirsiz monoklonal gamopati (MGUS) saptanmıştı. Yavaş ilerleyen kronik nöropatili altı olguda, EMG incelemesi hasta uyumsuzluğu, genel durum bozukluğu gibi çeşitli nedenlerle yapılamamıştı.

Tablo I'de CMT 1A, HNPP olguları ile mutasyon saptanmayan olguların klinik ve elektrofizyolojik bulguları özetlenmiştir. 
Tablo I: CMT 1 A, HNPP olguları ile mutasyon saptanmayan olguların klinik ve elektrofizyolojik bulguları

\begin{tabular}{|c|c|c|c|c|}
\hline & CMT 1A (n-25) (\%) & HNPP $(\mathrm{n}=10)(\%)$ & $\begin{array}{l}\text { Mutasyon } \\
\text { saptanmayan } \\
(\mathrm{n}=40)(\%)\end{array}$ & $\begin{array}{l}\text { Total } \\
(\mathrm{n}=75)(\%)\end{array}$ \\
\hline Ortalama Yas & $43,44 \pm 16,41$ & $38,4 \pm 15,31$ & $43,7 \pm 15,46$ & $42,87 \pm 16,82$ \\
\hline Min-max yas & $17-78$ & $14-64$ & 6.70 & 6.78 \\
\hline \multicolumn{5}{|l|}{ Cinsiyet } \\
\hline Errkek & $13(\% 52)$ & $8(980)$ & $24(\% 60)$ & $45(\% 60)$ \\
\hline Kadm & $12 \% 48)$ & $2(\% 20)$ & $16 \%$ & $30(\% 40)$ \\
\hline \multicolumn{5}{|l|}{ Aile öykhïsũ } \\
\hline Var & $21(\% 84)$ & $7 \% 70)$ & $8(\% 20)$ & $36 \%(\%)$ \\
\hline Yok & $4(\% 16)$ & $3(\% 30)$ & $32(\% 80)$ & $39(\% 52)$ \\
\hline \multicolumn{5}{|l|}{ Nörolojik Muayene Bulgusu } \\
\hline -Distal kas zanf ve atrofisis, arffeckshinoorefeleksi & $4 \% 16)$ & 0 & $27(\% 67,5)$ & $31(\% 41,33)$ \\
\hline 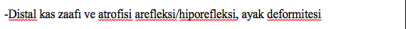 & $21(\% 84)$ & $2(\% 20)$ & 0 & $23(\% 30,66)$ \\
\hline -Bir periferil sinir dä̆lmuna uyan duysal ve motor bulgularar & 0 & 0 & $1(\%, 2,5)$ & $1 \%(\%, 339$ \\
\hline -Birden fazla periffrik s sinirde duyy kaybb ile birilikte asimertik distal kuvvetsizilik & 0 & $7 \% 70)$ & $7 \% 17,5)$ & $14(\% 18,60)$ \\
\hline -izole ayak defornitesi & 0 & $1 \% 10)$ & $5(\% 12,5)$ & $6(\% 8)$ \\
\hline \multicolumn{5}{|l|}{ EMG sonucu } \\
\hline - Uniform sensorimotor demiyelinizan polinöropati & $25 \%(100)$ & 0 & $1(\% 2,5)$ & $26(\% 34,66)$ \\
\hline - Uniform olmayan sensorimotor demivelinizan polinöropali & 0 & 0 & $4(\% 10)$ & $4(\%, 33)$ \\
\hline 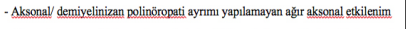 & 0 & 0 & $13(\% 32,5)$ & $13(\% 17,33)$ \\
\hline - Sensorimotor polinöropati zemininde birden fazla periferik sinirde tuzak & 0 & 10 & 0 & $10(\% 13,33)$ \\
\hline nëropati & 0 & 0 & $8(\% 220)$ & $8(\% 10,66)$ \\
\hline 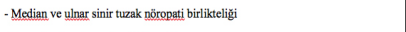 & 0 & 0 & $5(\% 12,5)$ & $5(\% 6,66)$ \\
\hline - Sensorimotar a aksonal poliñropati & 0 & 0 & $3(\%, 5)$ & $3(\%)$ \\
\hline 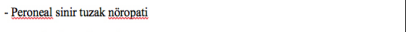 & 0 & 0 & $6(\% 15)$ & $6(\%)$ \\
\hline - EMG inclemesi yaplamayan & & & & \\
\hline
\end{tabular}

\section{TARTIŞMA}

Çalışmamızda PMP 22 gen analizi yapılan 75 hastanın klinik ve elektrofizyolojik özellikleri ile tanıya giden süreçleri analiz edilmiştir. Olguların 25 'ine $(\% 33,3)$ CMT $1 \mathrm{~A}$ ve 10 'unda $(\% 13,3)$ HNPP alt tipleri genetik olarak doğruland. $\mathrm{Bu}$ çalışma, hedeflenen gen panellerinin klinik ve elektrofizyolojik verilerle desteklendiğinde CMT moleküler tanısı için yararlı bir araç olduğuna dair kanıtlar sunmaktadır.

CMT 1A hastalığı yavaş ilerleyen bir bozukluk olup genellikle yaşamın ilk yirmi yılında bacaklarda güçsüzlük ile başlamaktadır. Hastalar; distal kas güçsüzlüğü, atrofi, duyu kayb1, hiporefleksi ve iskelet deformitesi (pes cavus, çekiç ayak parmakları gibi morfolojik özellikler) ile karakterize edilen "klasik CMT fenotipi" ile başvururlar (9). Çalışmamızda en sık muayene bulgusu distal kaslarda atrofi, zaaf ve hiporefleksi/arefleksi idi. Bu muayene bulgusunda mutasyon sıklığı düşük saptanmıştır ancak muayenede iskelet anormallikleri gibi fenotipik bulguların da eşlik etmesi önemli bir ipucu olup hastalık tanısına daha çok yönlendirdiği dikkati çekmektedir. Literatür ile benzer şekilde nöropati klinik bulguları ile başvuran CMT 1A hastalarında pozitif moleküler tanı oranı daha yüksek bulundu $(6,10,11)$.

Bazı CMT hastaları çok daha şiddetli hastalıkla daha erken klinisyene başvururken asemptomatik seyredenler yetişkinliğe kadar tespit edilememektedir. (12). Hastalık özellikle hayatın erken dönemlerinde asemptomatik olabildiğinden veya belirtiler hastalar tarafindan göz ardı edildiğinden tanı gözden kaçabilir. Her çalışmada bildirilen prevalansı etkileyen önemli bir faktör etkilenen bazı bireylerin semptomlarının hafif olması veya hiç semptom göstermemesidir (12). Çalışmamızda asemptomatik üç olgu, birinci derece akrabaları CMT 1A nedeniyle takip edilirken tesadüfi klinik bulgular saptanması ve istenen genetik incelemede PMP 22 duplikasyonunun tespit edilmesinden sonra tanı almıştır. Aynı gen defekti olan hastalarda klinik bulguların şiddeti oldukça farklı olabilir. Bu nedenle, hastaları ve ailelerini dikkatli bir klinik yaklaşımla değerlendirmek önemlidir (2). Öyküde uzun süreli nöromüsküler semptomların aranması ve ayrıntılı aile öyküsünün alınmasının yanında çekiç parmak, yüksek ayak arkı gibi ayak deformiteleri ve skolyoz gibi iskelet anormalliklerinin saptanması ayrıca, hasta yakınlarının da nörolojik değerlendirmelerinin yapılması önceden tahmin edilmeyen kalıtsal bir nöropatinin tanınmasında yol gösterici olacaktır. Çok sayıda akrabanın sistematik taranması da hastalığın erken tespiti için önemlidir (13).

CMT hastalarının büyük çoğunluğunda kalıtsal patern tanınamayabilir (6). Yoshimura ve arkadaşlarının çalışmasında sporadik vakaların tespit oranı \% 21,9 olarak rapor edilmiştir (11). Bir çok hastanın aile öyküsü olmadan başvurduğunu vurgulamak önemli olmakla birlikte aile öyküsünün olmamas1 genetik inceleme yapılmadan otozomal dominant kalıtımı dışlamak için yeterli değildir (11). Bunun yanında aile öyküsü kesin negatif olsa da herediter nöropati tanıs1 atlanmamalıdır. Aile öyküsü her zaman olmayabileceğinden klinik bulguların ve EMG bulgularının varlığında yine de herediter polinöropatiden şüphe etmek gereklidir. Çalışmamızda olguların büyük çoğunluğunda aile öyküsü mevcuttu. Aile öyküsü olmayan 4 olguda CMT 1 A, 3 olguda HNPP saptanmış olup bu durumun yeni bir mutasyon varlığ ile ilişkili olabileceği düşünülmüştür. Yeni bir mutasyon varlığının ortaya konulması için anne ve babanın genetik analizi yapılması gereklidir. Ancak erişkin hasta grubunda aile fertlerine ulaşılamadığından bu durum ortaya konulamamıştır. CMT'de de novo dominant vakalar nispeten sık görülür, bu nedenle bazı hastaların ailesinde CMT öyküsü olmayabilir (14). Çalışmamızda pozitif aile öyküsü artan pozitif test olasılığı ile ilişkiliydi. Öte yandan çalışmamızda aile öyküsü alınmamış olgularda da herediter polinöropatinin gösterilmiş olması, spesifik klinik ve elektromiyografi bulguları varlığında genetik test istenmesinin önemine işaret etmektedir.

Genetik testlerden önce yapılan elektrodiagnostik değerlendirmeler moleküler genetik çalışmalarda aday genlerin seçilmesinde ve semptomları olmayan hastaların tanımlanmasında oldukça faydalıdır (1,4,15-17). Sinir iletiminde uniform yavaşlama CMT hastalığını diğer edinilmiş demiyelinizan polinöropatilerden ayırt etmek için kullanılmıştır. Bir sinirin uzunluğu boyunca uniform yavaşlamanın görülmesi bütün sinirlerde ve sinirlerin bütün segmentlerinde iletimi aynı derece etkileyen kalıtsal bir nöropatiye işaret eder. Edinsel demiyelinizan polinöropatilerde ise multifokal veya heterojen iletim yavaşlamasıyla birlikte artmış temporal dispersiyon ve iletim bloğu gibi özellikler göstermektedir. Elektromiyografi incelemesinde sinir iletim çalışmalarında $38 \mathrm{~m} / \mathrm{sn}$ 'nin altında (genellikle yaklaşık $20 \mathrm{~m} / \mathrm{sn}$ ) altında uniform şekilde yavaşlamış sinir iletim hızları CMT1A'yı oldukça düşündürür (5). Bizim çalışmamızda da elektromiyografi incelemesinde uniform sensorimotor demiyelinizan polinöropati saptanan 25 olgunun tamamında PMP 22 duplikasyonu saptanmıştır. EMG incelemesinde uniform olmayan demiyelizan polinöropati saptanan olgularda ise 
mutasyon saptanmamıştır. Çalışmamızda fizik muayene bulgularına ek olarak elektrofizyolojik anormallik birlikteliğinde tanısal doğrulama oranının arttığını gözledik.

Elektrodiagnostik değerlendirmeler kalıtsal ve inflamatuar nöropati arasında örtüşmenin olduğu zorlayıcı hastaların yönetimininde de yol gösterici olabilir. CMT olgularında kronik inflamatuar demiyelinizan polinöropati (KIDP) hastalarındaki bulgularla çakışabilecek şekilde sinir iletiminde yavaşlama gösterebilir (16). CMT1A ve KIDP'nin klinik prezentasyonu ve aile öyküsü genellikle farklı olsa da, bazen de sinir iletim çalışmalarında sonuçlar benzer olup yaygın demiyelinizasyonu yansıtır. Kronik edinsel demiyelinizan nöropatili hastaların izlemlerinde immünmodülatuar tedaviye yanıt gözlenmemesi durumunda herediter nöropatiler açısından inceleme yapılması önerilmektedir. Çalışmamızda 5 KIDP olgusunda tedaviye yanıtsılık nedeniyle tanı yeniden gözden geçirilmiş ve bir olguda PMP 22 duplikasyonu saptanmıştır. Herediter demiyelinizan polinöropati hastalarında yanlış tanı gereksiz tedaviye, tedavi yan etkilerine bağlı güçlüklere ve zaman kaybına neden olabilir. Bu açıdan edinsel olduğu düşünülen demiyelinizan sensorimotor polinöropati hastalarında tedaviye yetersiz yanıt söz konusu olduğunda herediter polinöropati olasılığı göz ardı edilmememelidir.

Jeneralize polinöropatili hastaların elektrofizyolojik değerlendirilmesinde nöropatinin altında yatan primer patofizyolojiyi aksonal veya demiyelinizan olarak tanımlamak oldukça önemlidir. Mümkün olduğunca ikisinden birini birincil veya baskın anormallik olarak tanımlanmalıdır ancak birçok nöropati, bu patolojik değişikliklerin bir kombinasyonu ile karakterize olabilir (16). Ayrıca motor ve duysal yanıtların kaydedilemeyecek şekilde ağır aksonal etkilenimin olduğu durumlarda, bu ayrımı yapmak güç olabilir. Çalışmamızda elektromiyografi incelemesinde ağır aksonal etkilenim nedeniyle edinsel/herediter demiyelinizan polinöropati ayrımı yapılamayan 13 olguda CMT 1 A testi istenmiş olup sonuç hepsinde negatifti. Bu hastalarda CMT ile ilişkili başka genlerde mutasyon olabilir. Bu olgulardan 1 tanesinin klinik takiplerinde önemi belirsiz monoklonal gamopati (MGUS) teşhisi kondu.

HNPP hastalarında periferik sinirlerin mekanik traksiyonlara ve kompresyonlara hassasiyeti artmıştır. Hastalar başlangıçta asemptomatik olabilir. Hastalar tuzaklanmaya yatkın sinirleri etkileyen tekrarlayan ağrısız uyuşma ve güçsüzlük atakları ile başvururlar (15). Çalışmamızda HNPP'li 7 olguda birden fazla periferik sinirde duyu kaybı ile birlikte asimetrik distal kuvvetsizlik bulgusu varken 2 olguda distal kaslarda atrofi, hiporefleksi/arefleksi ve ayak deformitesi bulgusu mevcuttu. HNPP hastalarında sinir iletim çalışmaları median ve ulnar sinirin iletiminde ön kol segmentlerinde hafif yavaşlama ile birlikte uzamış distal latanslar, kompresyon bölgelerinde ulnar ve peroneal sinirlerin fokal yavaşlaması ve duyu sinir aksiyon potansiyellerinde yaygın düşüşler ile karakterize bir patern gösterir (15). Tekrarlayan fokal sinir palsilerine ek olarak çoğu hastada kronik yavaş ilerleyici sensorimotor polinöropati vardır. Bizim çalışmamızda da mutad tuzaklanma bölgelerinde birden fazla periferik sinirde tuzak nöropati tespit edilen, eş zamanlı sensorimotor aksonal polinöropati saptanan 10 olguda PMP 22 delesyonu saptanmıştır. Etyolojide açıklayıcı neden bulunamayan düşük ayak nedeniyle başvuran ve elektrofizyoloji incelemesinde de polinöropati bulguları olmaksızın peroneal tuzak nöropati tespit edilen 3 olguda mutasyon saptanmamıştır. Bu durum EMG incelemesinde tuzak nöropatiye eşlik eden sensorimotor polinöropati varlığında HNNP saptama olasılığının daha yüksek olacağı düşündürmektedir.

Graf ve arkadaşlarının retrospektif vaka serisinde CMT 1A hastalarında vincristin ve diğer kemoterapötik nörotoksik ajanların çok şiddetli reaksiyonlara neden olabildiği, açıklanamayan kronik nöropati ve ailede nöropati öyküsü bulunan hastalarda kanser kemoterapisine başlamadan önce CMT 1A'nın mutlaka ekarte edilmesi gerektiği bildirilmiştir (18). Bizim çalışmamızda da bir olgu ALL nedeniyle vincristin kullanımı olan motor liflerde ağır akson kaybına yol açan polinöropati olgusunda beklenmedik klinik kötüleşme karşısında ayırıcı tanı için genetik test istenmiş olup mutasyon saptanmamıştır.

Günümüze kadar yapılan genetik çalışmalar kalıtsal nöropatilerin etyolojileri ile bağlantılı olan birçok gen mutasyonlarının varlığını ortaya konmuştur. CMT ve ilişkili diğer periferik nöropatiler için moleküler tanı testleri oldukça önemlidir ancak bütün genetik test yöntemlerini içerecek şekilde rastgele uygulamalardan da kaçınmak maliyet açısından önemlidir (2). Bu nedenle klinisyenin hastayı uygun genetik teste yönlendirmesi zor bir görevdir. CMT alt tipinin tanımlanmasına yönelik tanısal yaklaşım için dikkatli fenotipik tanımlama, pes cavus, çekiç parmak ve skolyoz gibi iskelet deformiteleri varlığı, spastisite, piramidal belirtiler gibi bazı diğer klinik ipuçları, klinik ve elektrofizyolojik özellikler, kalıtım paterni klinisyenin hastayı uygun genetik test için yönlendirmesine yardımcı olabilir (3). Genetik test CMT için kesin tanı şekli olmasına rağmen, elektrofizyolojik testler, kalıtsal nöropatiden şüphelenilen hastaların değerlendirilmesinde hala ayrılmaz bir araçtır (19). Tanının akla gelmesi önemlidir ancak pahalı bir inceleme yöntemi olduğundan gereksiz istemden kaçınılmalı, uygun hasta ve hedefe yönelik uygun tetkik istenmelidir. Elektrofizyolojik inceleme sonuçlarının klinik bulgular 1şı̆̆ında değerlendirilmesi, ayırıcı tanı yapılırken genetik testlerin belirli hedeflere yönelik daraltılması klinisyenin doğru ve hızlı tanı koymasına yardımcı olabilir.

Çalışmamızın kısıtlılıkları hasta sayısının az olması ve CMT ile ilişkili olduğu bilinen tüm genleri analiz etmememizdir. CMT ile ilişkili genlerin geniş bir şekilde taranması muhtemelen mutasyon tespit oranını arttıracaktır. $\mathrm{Bu}$ çalışma, planlanan genetik test incelemelerinin çeşitliğini azaltmak ve tanısal isabet oranını artırmak için kapsamlı bir klinik ve elektrofizyolojik çalışmanın önemine işaret eder. 
Akan O. ve ark.

\section{SONUCG}

Spesifik klinik ve elektrofizyolojik ipuçlarınının araştırılarak hastaların uygun genetik testlere yönlendirilmesi klinisyenler için temel hedeflerdendir.

Etik Komite Onayı: Bu araştırma, ilgili tüm ulusal düzenlemelere, kurumsal politikalara ve Helsinki Bildirgesinin ilkelerine uygundur ve Prof. Dr. Cemil Taşcıŏglu Şehir Hastanesi etik komitesi tarafından onaylanmıştır (onay numarasi: 02.06.2020/151).

Hasta Onamı: Çalışma retrospektif olarak yürütülmüş olup hastalardan yazılı bilgilendirilmiş onam alınmamıştır.
Yazar Katkıları: Fikir - O.A.; Tasarım - O.A., TUA., B.E.; L.B.K.; Denetleme- O.A., TUA., B.E.; L.B.K KaynaklarO.A., TUA., B.E.; L.B.K.; Malzemeler- O.A., TUA., B.E.; L.B.K.; Veri Toplanması ve/veya İşlemesi- O.A., TUA., B.E.; L.B.K; Analiz ve/veya Yorum- O.A., TUA., B.E.; L.B.K.; Literatür Taraması- O.A., TUA., B.E.; L.B.K.; Yazıyı YazanO.A., TUA., B.E.; L.B.K.; Eleştirel İnceleme- O.A., TUA., B.E.; L.B.K.

Çıkar Çatışması: Yazarların beyan edecek çıkar çatışması yoktur.

Finansal Destek: Yazarlar bu çalışma için finansal destek almadıklarını beyan etmişılerdir. 


\section{KAYNAKLAR}

1. Pareyson D, Saveri P, Pisciotta C. New developments in Charcot-Marie-Tooth neuropathy and related diseases. Curr Opin Neurol 2017; 30(5):471-80.

2. Parman Y. Hereditary neuropathies. Curr Opin Neurol 2007; 20(5):542-7.

3. Saporta AS, Sottile SL, Miller LJ, Feely SM, Siskind CE, Shy ME: Charcot-Marie-Tooth disease subtypes and genetic testing strategies. Ann Neurol 2011; 69:22-33.

4. Berciano J, García A, Gallardo E, Peeters K, Pelayo-Negro AL, Álvarez-Paradelo S, vd. Intermediate Charcot-Marie-Tooth disease: an electrophysiological reappraisal and systematic review. J Neurol 2017; 264(8):1655-77.

5. Patzkó A, Shy ME. Update on Charcot-Marie-Tooth disease. Curr Neurol Neurosci Rep 2011; 11(1):78-88.

6. Østern R, Fagerheim T, Hjellnes H, Nygård B, Mellgren SI and Nilssen $\varnothing$. Diagnostic laboratory testing for Charcot Marie Tooth disease (CMT): the spectrum of gene defects in Norwegian patients with CMT and its implications for future genetic test strategies. BMC Med Genet 2013; $14: 94$

7. Van den Bergh PYK, Hadden RD, Bouche P, Hadden RDM, Bouche P, Cornblath DR, Hahn A, Koski CL, Leger JM, Nebil-Orazio E, Pollard J, Sommer C, van Doorn PA, van Schaik IN. European Federation of Neurological Societies/Peripheral Nerve Society (EFNS/PNS) guideline on management of chronic inflammatory demyelinating polyradiculoneuropathy: report of a joint task force of the European Federation of Neurological Societies and the Peripheral Nerve Society-first revision. Eur J Neurol 2010; 17: 356-363.

8. Mccorquodale D, Smith AG. Clinical electrophisiology of axonal polyneuropathies. Handbook of Clinical Neurology 2019; 161:217-240.

9. Jani-Acsadi A, Ounpuu S, Pierz K, Acsadi G. Pediatric Charcot-Marie-Tooth disease. Pediatr Clin North Am 2015; 62(3):767-86.

10. Cortese A, Wilcox J E, Polke JM, Poh R, Skorupinska M, Rossor AM, Laura M, Tomaselli PJ, Houlden H, Shy $\mathrm{ME}$, and Reilly MM. Targeted next-generation sequencing panels in the diagnosis of Charcot-Marie-Tooth disease. Neurology 2020; 94 (1):51-61.

11. Akiko Yoshimura, Jun-Hui Yuan, Akihiro Hashiguchi, Masahiro Ando, Yujiro Higuchi, TomonoriNakamura, Yuji Okamoto,Masanori Nakagawa,Hiroshi Takashima. Genetic profile and onset features of 1005 patients with
Charcot-Marie-Tooth disease in Japan. J Neurol Neurosurg Psychiatry 2019; 90(2):195-202.

12. Fridman V, Bundy B, Reilly MM, Pareyson D, Bacon C, Burns J, Day J, Feely S, Finkel RS, Grider T, Kirk CA, Herrmann DB, Laura M, Li J, Lloyd T, Sumner CJ, Muntoni F, Piscosquito G, Ramchandren S, Shy R, Siskind CE, Yum SW, Moroni I, Pagliano E, Zuchner S, Scherer SS, Shy ME. CMT subtypes and disease burden in patients enrolled in the inherited Neuropathies Consortium natural history study: a cross- sectional analysis. Inherited Neuropathies Consortium. J Neurosurg Pschiatry 2015; 86(8):873-8.

13. Barreto LCLS, Oliveira FS, Nunes PS, Costa IMPF, Garcez CA, Goes GM, Neves ELA, Quitans JSS, Araújo AAS. epidemiologic study of Charcot-Marie-Tooth Disease: A systematic review. Neuroepidemiology 2016; 46(3):157-65.

14. Murphy SM, Laura M, Fawcett K, Pandraud A, Liu YT, Davidson GL, Rossor AM, Polke JM, Castleman V, Manji H, Lunn MP, Bull K, Ramdharry G, Davis M, Blake JC, Houlden H, Reilly MM. Charcot-Marie-Tooth disease: frequency of genetic subtypes and guidelines for genetic testing. J Neurol Neurosurg Psychiatry 2012; 83(7):706-10.

15. Bowley MP, Chad DA. Clinical neurophysiology of demyelinating polyneuropathy. Handb Clin Neurol 2019; 161:241-68.

16. Stanton M, Pannoni V, Lewis RA, Logigian EL, Naguip D, Shy ME, Cleland J, Herrmann DN. Dispersion of compound muscle aciton potential in hereditary neuropathies and chronic inflammatory demyelinating polyneuropathy. Muscle Nerve 2006 ; 34 (4):417-22.

17. Morena J, Gupta A, Hoyle JC. Charcot-Marie-Tooth: From Molecules to Therapy. Int J Mol Sci 2019; 20(14):3419.

18. Graf WD, Chance PF, Lensch MW, Eng LJ, Lipe HP, Bird TD. Severe vincristine neuropathy in Charcot-Marie-Tooth disease type 1A. Cancer 1996; 77(7):1356-62.

19. England JD, Gronseth GS, Franklin G, Carter GT, Kinsella LJ, Cohen JA, Asbury AK, Szigeti K, Lupski JR, Latov N, Lewis RA, Low PA, Fisher MA, Herrmann D, Howard JF, Lauria G, Miller RG, Polydefkis M, Sumner AJ. Evaluation of distal symmetric polyneuropathy: the role of laboratory and genetic testing (an evidence-based review). Muscle Nerve 2009; 39:116125. 